\title{
Growth-promoting activity of tryptic digest of caseinomacropeptide for Lactococcus lactis subsp lactis
}

\author{
S Bouhallab, C Favrot, JL Maubois \\ INRA, Laboratoire de Recherches de Technologie Laitière, 65 rue de St Brieuc, \\ 35042 Rennes, France
}

(Received 13 November 1992; accepted 30 November 1992)

Summary - Tryptic digest of caseinomacropeptide (C-terminal part of $k$-casein) was separated into 2 fractions by ultrafiltration membrane (cut-off point $3000 \mathrm{Da}$ ). Both fractions strongly stimulated, in a dose-response-dependent manner, Lactococcus lactis subsp lactis CNRZ 1076 growth in reconstituted skim milk. Growth rates were 2-fold higher than that observed in the control culture.

caseinomacropeptide / hydrolysis / stimulation / Lactococcus lactis

Résumé - Stimulation de la croissance de Lactococcus lactis subsp lactis par l'hydrolysat trypsique du caséinomacropeptide. L'hydrolysat trypsique du caséinomacropeptide (fraction Cterminale de la caséine $\kappa$ ) a été séparé en 2 fractions par ultrafiltration sur membrane ayant un seuil de coupure de $3000 \mathrm{Da}$. Ces 2 fractions stimulent fortement la croissance de Lactococcus lactis subsp lactis CNRZ 1076 en milieu lait écrémé selon un effet dont l'intensité dépend de la dose utilisée. Le taux de croissance cellulaire est multiplié par deux par rapport à celui observé sur le lait témoin.

caséinomacropeptide / hydrolyse / stimulation / Lactococcus lactis

\section{INTRODUCTION}

Caseinomacropeptide (CMP), the glycosylated C-terminal portion (64 amino-acids) of $\kappa$-casein, is released by rennet action during milk clotting. Tryptic hydrolysis of this fragment leads to the liberation of small peptides (SP) (4-7 amino acids) from the N-terminal part (Léonil and Mollé,
1990). These molecules constitute a family of bioactive peptides with antithrombotic activity (Jollès et al, 1986; Maubois et al, 1991). The high molecular weight difference between these bioactive peptides $\left(M_{\mathrm{r}}<700 \mathrm{Da}\right)$ and complementary fragments $\left(M_{\mathrm{r}}>6000 \mathrm{Da}\right)$ was exploited for continuous separation of SP in the membrane reactor (Bouhallab et al, 1992). 
Moreover, SP-enriched permeate could be a potential nutriment for lactic acid bacteria because it has been reported that peptides of 4-6 residues and less are favourable for microorganism growth (Desmazeaud and Hermier, 1973; Law et al, 1976).

The purpose of this work was to study the effect of separated tryptic digest of CMP on Lactococcus lactis subsp lactis CNRZ 1076 growth in skim milk media. Cell viability determination and acidification rate of milk were used to assess growthpromoting activity of these molecules.

\section{MATERIALS AND METHODS}

Substrate, caseinomacropeptide, was prepared according to Brulé et al (1980). Trypsin (EC 3.4.21.4) was from Novo Nordisk Bioindustrie SA (Fontenay-sous-Bois, France). Lactococcus lactis subsp lactis CNRZ 1076 was used as assay organism.

\section{Tryptic hydrolysis of CMP}

Ten g of CMP were incubated with trypsin (E/S molar ratio $=1: 210$ ) in $650 \mathrm{ml}$ distilled water at $\mathrm{pH} 8$ and $40^{\circ} \mathrm{C}$. The $\mathrm{pH}$ was controlled by continuous addition of $0.1 \mathrm{~N} \mathrm{NaOH}$ using pH-stat (Metrohm, Roucaire, France). After $3 \mathrm{~h}$, the hydrolysate was concentrated to $125 \mathrm{ml}$ using a Filtron minisette system (Pharmacia, SaintQuentin-en-Yvelines, France) equipped with an ultrafiltration membrane of $3000 \mathrm{Da}$ cut-off. The permeate $(500 \mathrm{ml})$ enclosing SP was freezedried. The retentate (LP fraction) was diafiltered with 2 vol distilled water and then extensively dialysed by using Spectra-por $1000 \mathrm{Da}$ cut-off dialysis tubing. Amino acid composition was carried out according to Bidlingmeyer et al (1984).

\section{Culture conditions and growth media}

Lactococcus lactis cells were stored in M17 medium with $15 \%(w / w)$ glycerol added at $-20^{\circ} \mathrm{C}$.
Pre-culture and cells preparation were carried out in skim milk according to Juillard and Richard (1989). For growth experiments, exponentially growing cells were used to inoculate reconstituted skim milk (Lait G, ITG, La Roche sur Foron, France) at $10^{4} \mathrm{CFU} / \mathrm{ml}$. Incubation temperature was $30^{\circ} \mathrm{C}$.

\section{Acidification rate and cells viability}

Acidification rate of culture medium by bacteria was monitored using multi-pH meter (Solomat, Evry, France). Bacterial enumeration was carried out by plating sample dilutions on M17 medium with a Spiral plater (Interscience, St Nomla-Bretèche, France). Plates were incubated for $24 \mathrm{~h}$ at $30^{\circ} \mathrm{C}$ before reading. Growth rate $(\mu)$ was calculated by linear regression using Monod's equation (Monod, 1958).

\section{Activity tests}

Potential activities of peptide solutions on acid production were determined by addition of $1 \mathrm{ml}$ of each adequate dilution to $19 \mathrm{ml}$ culture medium. The effects of peptide on bacterial growth were determined by addition of $5 \mathrm{ml}$ of peptide solution to $95 \mathrm{ml}$ culture medium. For control cultures, water was added instead of peptide solutions.

\section{RESULTS AND DISCUSSION}

By using ultrafiltration membrane separation technique, tryptic hydrolysate of CMP was separated into 2 groups of peptides: SP $\left(M_{\mathrm{r}} 500-700 \mathrm{Da}\right)$ and LP (average $M_{\mathrm{r}}$ $6000 \mathrm{Da})$ (Bouhallab et al, 1992). Both fractions stimulate Lactococcus lactis growth in reconstituted skim milk. As shown in figure 1 , they strongly promote the $\mathrm{pH}$ decrease of the culture medium in a dose-response-dependent manner. The minimal concentration of SP required for detecting promoting activity under our conditions was $0.2 \mu \mathrm{g} / \mathrm{ml}$. The growth promot- 


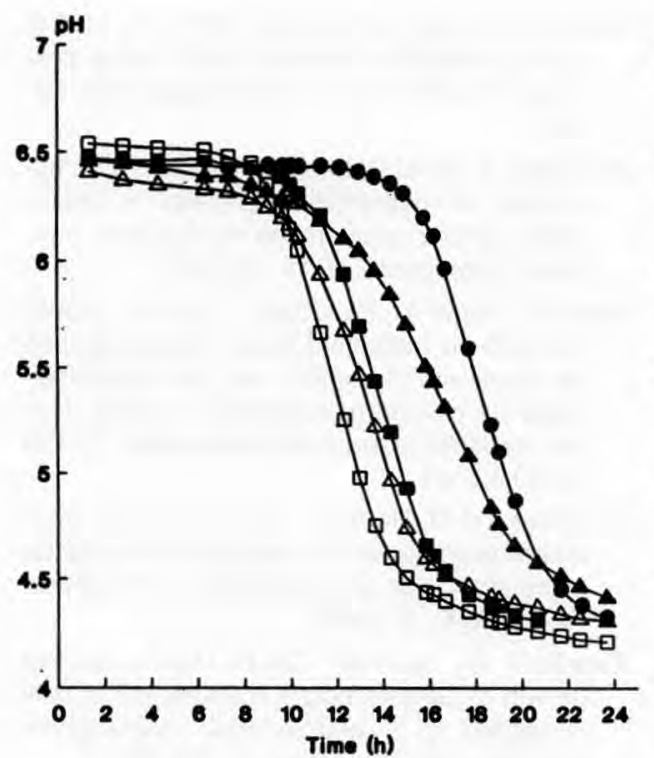

Fig 1. Acid production activity of $L$ lactis ( --$)$

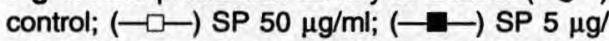
$\mathrm{ml} ;(-\Delta-)$ LP $2 \mathrm{mg} / \mathrm{ml}$; (- - - $0.5 \mathrm{mg} / \mathrm{ml}$. Growth experiments were carried out in $20 \mathrm{ml}$ reconstituted skim milk.

Activité acidifiante de $\mathrm{L}$ lactis (-) témoin; $(-\square)(-\square)$ petits peptides à 50 et $5 \mu \mathrm{g} / \mathrm{ml}$ respectivement; $(-\Delta-)(-\mathbf{\Delta}-)$ gros peptides à 2 et $0,5 \mathrm{mg} / \mathrm{ml}$ respectivement. La croissance était réalisée dans $20 \mathrm{ml}$ de lait écrémé reconstitué.

ing-property of CMP-derived peptides was confirmed by enumeration of viable cells (fig 2). Growth rates were 2-fold higher when peptidic fractions were added than that of control culture. These observed activities of CMP derived fractions were much higher than that obtained by addition of whole CMP in the same conditions (unpublished results).

Mechanisms through which CMPderived peptides induce Lactococcus lactis growth are probably different. The fractions tested differ by their average $M_{r}$ as well as in amino acid composition (table I). They

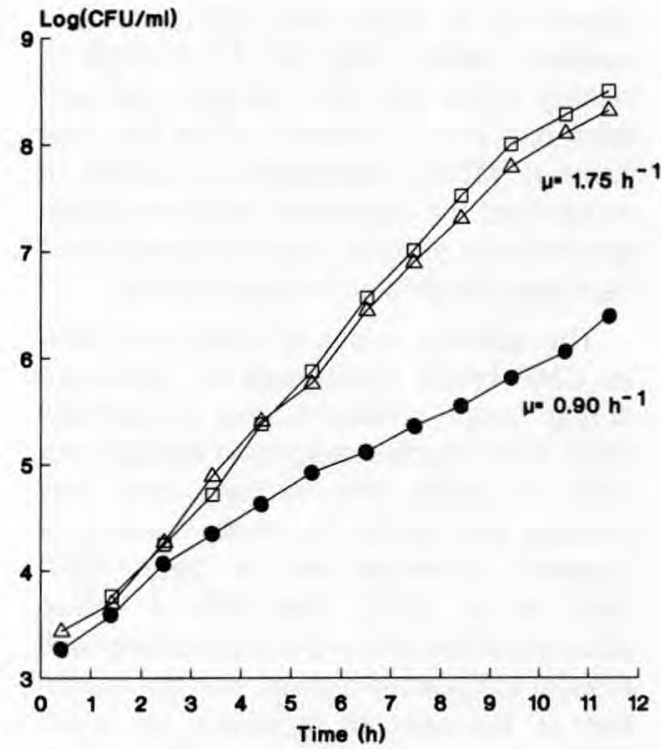

Fig 2. Effects of SP $(50 \mu \mathrm{g} / \mathrm{ml})(-\square-)$ and LP (2 $\mathrm{mg} / \mathrm{ml})(-\Delta-)$ on $L$ lactis growth as determined by cells enumeration on M17 medium (-) control culture. $\mu=$ growth rate.

Effets des petits peptides $(50 \mu \mathrm{g} / \mathrm{ml})(\square-)$ et des gros peptides $(2 \mathrm{mg} / \mathrm{ml})(-\Delta-)$ dérivés du CMP sur la viabilité $d u$ L lactis. (-) Témoin. $\mu=$ taux de croissance.

Table I. Amino acid composition of the fractions derived from CMP.

Composition en acides aminés des 2 fractions obtenues par hydrolyse trypsique du CMP.

$S P$

LP

Ala1a; Asn ${ }^{1} ;$ Asp $^{1} \quad \mathrm{Ala}^{5 / 4 *} ; \mathrm{Asn}^{2} ; \mathrm{Gln}^{1} ; \mathrm{Glu}^{8 \mathrm{~b}}$ Gln ${ }^{1} ; \| l e^{\text {b }} ;$ Lys $^{3}$ Met $^{1 \mathrm{~b}}$; Pro $^{2}$ Gly ${ }^{1}$; lle ${\text { A/5b*; Leu }{ }^{\text {b; }} \text { Pro }}^{6}$; Ser6; Thr ${ }^{11 / 12^{*}} ;$ Val $^{6 b}$; Asp $^{1 *}$

a Mol amino acid/mol CMP; b essential amino acids according to Marshall and Law (1983); SP: small peptides; LP: large peptides; ${ }^{*}$ from sequence data of CMP variants B/A, Grosclaude et al (1972). 
cannot act as simple essential amino acid suppliers seeing that the SP fraction is lacking in the His, Glu, Leu and Val residues and the LP fraction in His and Met (table I). More investigation is needed to understand the absorption and stimulation mechanisms of both fractions as well as of each peptide present in both mixtures.

The question arises whether such similar CMP tryptic hydrolysate is produced during usual cheesemaking technology. Most of the studies describing nitrogen nutrition of lactic acid bacteria from milk proteins are related to whole caseins or B-casein (Exterkate and de Veer, 1987; Smid et al, 1991). Very little is known about peptides derived from $\kappa$-casein with respect to bacterial growth, with the exception of Bifidobacterium genus for which Poch and Bezkorovainy (1991) have reported that $\kappa$-casein was the main microbial growth promoter and that the active component was located in the para $\kappa$-casein part. No activity of the carbohydrate moiety was detected in this latter study in contrast to what had been previously described by Azuma et al (1984). It appears, nevertheless, that CMP can be split by cell wall located proteinase of Lactococcus lactis but is a poor substrate for the partially purified enzyme (Monnet et al, 1992).

However, the high promoting growth activity of CMP-derived peptides the smallest of which ones are known as possessing antithrombotic activity emphasizes the interest in investigating the mechanisms inducing the phenomenon described in this study.

\section{REFERENCES}

Azuma N, Yamauchi K, Mitsuoka T (1984) Bifidus growth-promoting activity of a glycomacropeptide derived from human $\kappa$-casein. Agric Biol Chem 48, 2159-2162
Bidlingmeyer BA, Cohen SA, Tarvin TL (1984) Rapid analysis of amino acids using precolumn derivatization. J Chromatogr 336, 93104

Bouhallab S, Mollé D, Léonil J (1992) Tryptic hydrolysis of caseinomacropeptide in membrane reactor: preparation of bioactive peptides. Biotechnol Lett 14, 805-810

Brulé G, Roger L, Fauquant J, Piot M (1980) Procédé de traitement d'une matière à base de caséines ccntenant des phosphocaséinates de cations monovalents ou leurs dérivés, produits obtenus et applications. Fr Pat No 8002281

Desmazeaud M, Hermier J (1973) Effet de fragments peptidiques du glucagon vis-à-vis de la croissance de Streptococcus thermophilus. Biochimie 55, 679-684

Exterkate FA, de Veer GJCM (1987) Optimal growth of Streptococcus cremoris HP in milk is related to $\beta$ - and $\kappa$-casein degradation. Appl Microbiol Biotechnol 25, 471-475

Grosclaude F, Mahé MF, Mercier JC, RibadeauDumas B (1972) Localisation des substitutions d'acides aminés différenciant les variants $A$ et $B$ de la caséine $\kappa$ bovine. Ann Génét Sél Anim 4, 515-521

Jollès $P$, Levy-Toledano $S$, Fiat $A M$, Soria $C$, Gillessen D, Thomaidis A, Dunn FW, Caen JP (1986) Analogy between fibrinogen and casein. Effect of an undecapeptide isolated from $\kappa$-casein on platelet function. Eur $J$ Biochem 158, 379-382

Juillard V, Richard J (1989) Étude de l'interaction entre souches protéolytiques de streptocoques lactiques mésophiles et leurs variants non protéolytiques, au cours de leur croissance dans le lait. Lait 69, 291-304

Law BA, Sezgin E, Sharpe ME (1976) Amino acid nutrition of some commercial cheese starters in relation to their growth in peptonesupplemented whey media. J Dairy Res 43 , 291-300

Léonil J, Mollé D (1990) Liberation of tryptic fragments from caseinomacropeptide of bovine $\mathrm{K}$-casein involved in platelet function. $\mathrm{B}$ ochem J 271, 247-252

Maubois JL, Léonil J, Trouvé R, Bouhallab S (1991) Les peptides du lait à activité physiologique. III. Peptides du lait à effet cardiovasculaire : activités antithrombotique et antihypertensive. Lait 71, 249-255 
Marshall VME, Law BA (1983) The physiology and growth of dairy lactic-acid bacteria. In: Advances in the Microbiology of Cheese and Fermented Milk (Davies FL, Law BA, eds) Elsevier, New York

Monnet V, Ley JP, Gonzalez S (1992) Substrate specificity of the cell envelope-located proteinase of Lactococcus lactis subsp lactis NCDO 763. Int J Biochem 24, 707-718
Monod J (1958) Recherches sur La Croissance des Cultures Bactériennes. Hermann, Paris

Poch M, Bezkorovainy A (1991) Bovine milk $\kappa$ casein trypsin digest is a growth enhancer for the genus Bifidobacterium. I Agric Food Chem 39, 73-77

Smid EJ, Poolman B, Konings WN (1991) Casein utilization by lactococci. Appl Environ Microbiol 57, 2447-2452 